
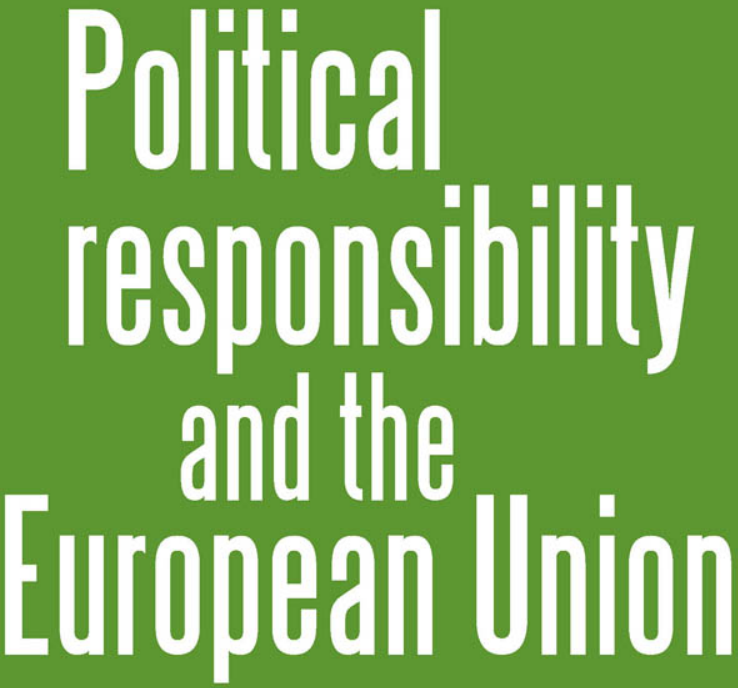

Myrto Tsakatika

Myrto Tsakatika - 9781847792365

Downloaded from manchesterhive.com at $04 / 26 / 2023$ 02:14: 04 AM 


\section{POLITICAL RESPONSIBILITY AND THE EUROPEAN UNION}

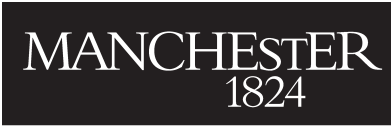

Manchester University Press 
This page intentionally left blank 


\title{
POLITICAL RESPONSIBILITY AND THE EUROPEAN UNION
}

\author{
Myrto Tsakatika
}

Manchester University Press

Manchester and New York

distributed in the United States exclusively by Palgrave Macmillan 
The right of Myrto Tsakatika to be identified as the author of this work has been asserted by her in accordance with the Copyright, Designs and Patents Act 1988.

Published by Manchester University Press

Oxford Road, Manchester M13 9NR, UK

and Room 400, 175 Fifth Avenue, New York, NY 10010, USA

www.manchesteruniversitypress.co.uk

Distributed in the United States exclusively by

Palgrave Macmillan, 175 Fifth Avenue, New York,

NY 10010, USA

Distributed exclusively in Canada by

UBC Press, University of British Columbia, 2029 West Mall,

Vancouver, BC, Canada V6T 1 Z2

British Library Cataloguing-in-Publication Data

A catalogue record for this book is available from the British Library

Library of Congress Cataloging-in-Publication Data applied for

ISBN 9780719075155 hardback

EISBN 9781847792365

First published 2008

$\begin{array}{llllllllllllllllllll}17 & 16 & 15 & 14 & 13 & 12 & 11 & 10 & 09 & 08 & 10 & 9 & 8 & 7 & 6 & 5 & 4 & 3 & 2 & 1\end{array}$

Typeset by Special Edition Pre-press Services

www.special-edition.co.uk

Printed in Great Britain

by CPI Antony Rowe Ltd, Chippenham, Wiltshire 